\title{
A CRISE E A CONVERGÊNCIA DAS NORMAS DE CONTABILIDADE NO BRASIL ${ }^{1}$
}

\section{THE CRISIS AND THE CONVERGENCE OF THE ACCOUNTING NORMS IN BRAZIL}

\section{LA CRISIS Y LA CONVERGENCIA DE LAS NORMAS DE CONTABILIDAD EN BRASIL}

\author{
FERNANDO CAIO GALDI \\ Doutor em Controladoria e Contabilidade \\ Professor Associado da FUCAPE BUSINESS SCHOOL \\ fernando.galdi@fucape.br
}

A atual crise levantou inúmeras questões sobre a organização e regulamentação do sistema financeiro internacional e trouxe consigo oportunidades e ameaças ao desenvolvimento das normas internacionais de Contabilidade (IFRSs). Em carta endereçada ao presidente George W. Bush para o encontro ocorrido entre os líderes do G20 em 15 de novembro em Washington, o Chairman dos Trustees do IASB, Gerrit Zalm, relata2: "O propósito desta carta é informar aos líderes dos países do G20 qual o papel do IASB, um órgão independente com o objetivo de desenvolver um conjunto único de normas contábeis globais de alta qualidade, em relação às questões que emanaram da crise de crédito [...]".

$1 \quad$ O autor agradece os comentários e sugestões ao texto feitos pelo professor Nelson Carvalho.

2 Tradução livre de: "The purpose of this letter is to inform the leaders of G20 countries of the role that the IASB, the independent body charged with developing a single set of high quality, global accounting standards, is playing in addressing issues emanating from the credit crisis". Disponível na íntegra em www.iasb.org 
De fato a carta endereçada ao G20 tinha como objetivo relatar as posições e as atitudes do IASB e deixar claro aos chefes de Estado que a entidade tem trabalhado com o objetivo de, mediante mensurações adequadas e divulgações consistentes, contribuir para minimizar os impactos da crise e desenvolver mecanismos que possam mitigar o aparecimento de novos eventos dessa natureza. Afinal, muitos aclamaram a Contabilidade, em especial a figura do valor justo para os instrumentos financeiros - fair value -, como um dos potencializadores da crise. $O$ argumento segue na linha de que balanços que utilizam como base de mensuração o valor justo (e isto é verdade para grande parte dos ativos das instituições financeiras) levam mais volatilidade para o mercado. Em momentos de crise e pânico, os ativos estariam subprecificados e o patrimônio das empresas subavaliado. Isso geraria, no entender desses críticos do valor justo, um círculo vicioso que retroalimentaria o mercado com informações negativas, o que geraria um novo ciclo de desvalorizações.

A idéia de que a informação correta (valor justo) em tempos de crise prejudica o mercado é similar a se imaginar que um paciente que fosse diagnosticado com uma doença grave estaria melhor se não soubesse dessa informação. Se o médico não o avisasse, ele certamente não sofreria o impacto de curto prazo (apesar de muitas vezes já sentir os sintomas), que é o desespero de saber que possui a doença. Em compensação, se o médico não o informasse e providências não fossem tomadas, com certeza no médio/longo prazo o paciente viria a falecer. Sem a informação não haveria como o paciente lutar contra a doença que o comete. Essa seria a opção ao abandonar a mensuração pelo valor justo para os instrumentos financeiros. Seria apenas esperar para o enterro. Enterro dos acionistas, credores e outros financiadores que confiaram seus recursos aos gestores da empresa, esperando obter, no mínimo, informações transparentes sobre o seu desempenho. A utilização do valor justo possibilita que os financiadores das empresas decidam como melhor alocar seus recursos. Isso deve ser resguardado como missão da contabilidade, mesmo em momentos de crise. E essa tem sido a posição do IASB.

Vale lembrar que toda crise tem fortes conseqüências políticas e isso poderá trazer impactos no atual processo de convergência das normas de contabilidade. No exterior, as pautas de discussões sobre o sistema financeiro passam a tratar de assuntos diretamente ligados à crise. Nesse sentido, pode-se esperar uma desaceleração nas mudanças que vêm ocorrendo, principalmente no mercado norte-americano, pois a atual estrutura do sistema financeiro talvez deva ser repensada. Por outro lado, a nomeação de Paul Volcker (ex-chairman da Fundação IASCF e ex-chairman do Federal Reserve Bank dos EEUU) como comandante do Conselho Assessor para a Recuperação Econômica pode contribuir para evitar uma possível desaceleração do processo de convergência. Isso porque Volcker sempre esteve fortemente envolvido com a evolução da normatização contábil e a considera como um fator essencial para prover informações financeiras necessárias ao adequado funcionamento dos mercados. 
No Brasil, onde o processo anda a passos largos e diversas mudanças são necessárias para que os cronogramas colocados pela CVM e pelo Banco Central sejam atendidos, os impactos da crise na convergência contábil também devem ser sentidos de alguma maneira; no entanto, como os bancos brasileiros não se envolveram nas operações de subprime loans, tais impactos se darão provavelmente no reconhecimento e divulgação de operações com derivativos, até o momento restritas a empresas não bancárias.

Até agora (05/dez/08) o CPC, órgão responsável por elaborar as normas de contabilidade brasileiras com objetivo de convergência às normas internacionais, já emitiu os seguintes pronunciamentos:

- Pronunciamento Conceitual Básico - Estrutura conceitual para a elaboração e apresentação das demonstrações contábeis;

- $\quad$ CPC 01 - Redução ao valor recuperável de ativos;

- $\quad$ CPC 02 - Efeitos das mudanças nas taxas de câmbio e conversão de demonstrações contábeis;

- $\quad$ CPC 03 - Demonstração dos fluxos de caixa;

- $\quad$ CPC 04 - Ativo Intangível;

- $\quad$ CPC 06 - Operações de Arrendamento Mercantil;

- $\quad$ CPC 07 - Subvenção e Assistência Governamentais;

- $\quad$ CPC 08 - Custos de Transação e Prêmios na Emissão de Títulos e Valores Mobiliários;

- $\quad$ CPC 09 - Demonstração do Valor Adicionado;

Os pronunciamentos acima explicitam a existente complexidade para o reconhecimento, mensuração e evidenciação das transações. Novos pronunciamentos, que já estão a caminho (atualmente em audiência pública ou os que já tiveram esse prazo encerrado), também vêm somar-se a essa complexidade. São eles: CPC 05 - Partes relacionadas; CPC 10 - Pagamentos baseados em ações; CPC 11 - Contratos de Seguros; CPC 12 - Ajuste a valor presente; CPC 13 - Adoção Inicial da Lei n. ${ }^{\circ}$ 11.638/07; CPC 14 - Instrumentos financeiros: Reconhecimento, Mensuração e Evidenciação; e CPC 15 - Combinação de negócios.

Somados às aplicações dos referidos pronunciamentos, os tópicos requeridos pela Lei n. ${ }^{\circ} 11.638 / 07$ e suas implicações tributárias (item que acaba de ser abordado na recente Medida Provisória sobre aspectos fiscais) torna o ambiente contábil brasileiro extremamente complexo neste momento. Esta complexidade deve ser enfrentada de frente pelas empresas e pelos profissionais que de alguma maneira estão envolvidos com a área. Apesar das dificuldades de adaptação à nova realidade contábil brasileira, especialmente neste momento de crise, as empresas devem se esmerar no preparo de equipes e de processos de identificação internos voltados ao pleno atendimento às determinações legais e normativas, visando prestar informações financeiras de alta qualidade e transparentes para o mercado. 
Adicionalmente, não podemos esquecer as mudanças na área de Contabilidade Pública. No dia 26/08/2008, o governo brasileiro anunciou, por meio da Portaria n. ${ }^{\circ} 184$ do Ministério da Fazenda, que as normas brasileiras de Contabilidade aplicadas ao setor público também vão convergir para as normas internacionais pertinentes. Isso representará uma maior transparência na prestação de contas e uma melhoria significativa na qualidade da informação para os gestores públicos. A informação contábil passará a ser mais adequada às necessidades dos administradores do governo e mais acessível para nós, pagadores de impostos. Assim, espera-se melhorar o monitoramento e fazer com que o dinheiro público seja utilizado cada vez mais de forma eficiente.

Todas essas mudanças advêm do esforço e do envolvimento de vários órgãos relacionados com a profissão contábil. Cabe destacar o papel que o Conselho Federal de Contabilidade (CFC) tem exercido nesse processo. O esforço do CFC é visível, e fica claro pelo empenho e pela eficiência de sua presidente, Maria Clara Cavalcante Bugarim. O 18. ${ }^{\circ}$ Congresso Brasileiro de Contabilidade, ocorrido em Gramado-RS, entre 24 e 28 de agosto deste ano, deu claras evidências da revolução pela qual a Contabilidade brasileira está passando. No mesmo evento estiveram presentes o Presidente Lula; a governadora do Rio Grande do Sul, Yeda Crusius; o empresário Antoninho Marmo Trevisan; o secretárioexecutivo do Ministério da Fazenda, Nelson Machado, além de diversos outros políticos e importantes representantes de agências do governo. Adicionalmente, figuras relevantes no mundo contábil e empresarial como Pedro Malan (à época presidente do Conselho de Administração do Unibanco e membro brasileiro no Conselho Curador da Fundação IASCF), Fermin Del Valle (presidente da IFAC), Nelson Carvalho (à época presidente do Conselho Consultivo de Normas do IASB, atual membro do CPC), Agustín Lizardo (Presidente da AIC) e Eliseu Martins (atual diretor da CVM e que foi homenageado com a Medalha Mérito Contábil João Lyra) também estiveram presentes e devem ser citadas como propulsores das recentes alterações.

Nesse ambiente extremamente desafiador, o profissional deve ficar atento para que nenhuma das alterações o surpreenda. A busca por informação e atualização é necessária. A crise não deve dispersar os esforços no processo de convergência. Pelo contrário, deve servir de incentivo para que as alterações sejam feitas de maneira a suprir as demandas dos usuários das informações financeiras. 